\title{
miRNA-141 as the Biomarker for Human Cancers
}

\author{
Thuan Duc Lao, Phuong Kim Truong and Thuy Ai Huyen Le* \\ Department of Pharmaceutical and Medical Biotechnology, Faculty of Biotechnology, \\ Ho Chi Minh City Open University, Ho Chi Minh City, Vietnam; thuy.Iha@ou.edu.vn
}

\begin{abstract}
microRNA (miRNA) is considered to be a pivotal role in human numerous biological process, and their abnormal expression that functions either as tumor suppressor or oncogenes results in human cancer initiation and development microRNA-141 (miR-141), belonged to the miR-200 family, located at 12 p13.31 and is also found to be abundantly expressed in many human cancers. Additionally, Prognostic and predictive miR-141 signatures have been defined for a variety of cancer types. This review summarized the biogenesis and processing of miRNA, as well as the roles of miR-141 in human cancer pathways, its targets and the potential utility of miR-141 as prognostic biomarkers.
\end{abstract}

Keywords: Biomarker, Human Cancer, microRNA, microRNA-141

\section{Introduction}

microRNAs (miRNA, miR), originally discovered in Caenorhabditis elegans are the small class of endogenous, functional non-coding RNAs, and highly conserved and widely found in animals, plants, protists, viruses (represents $\sim 20$ nucleotides $)^{1-4}$. miRNA regulates gene expression by binding to sequences in $3^{\prime}$-untranslated region (3'-UTR) of their target mRNAs, resulting in the repression and/or degradation of mRNA, proven to be associated to a wide range of biological processes such as cell division, proliferation, differentiation, apoptosis, metastasis, stress responses etc ${ }^{1,5-7}$. In the past decades, growing evidences indicated that miRNAs have been implicated as both oncogenes and tumor suppressors that the abnormal expression (positive regulation or downregulation) of miRNAs contributes to various human tumor pathogenesis $^{3,7-11}$. This current review is aimed to summarize the biogenesis and processing of miRNA, as well as the roles of miR-141 in human cancer pathways, its targets and the potential utility of miR-141 as prognostic biomarkers.

\section{Biogenesis and Processing of miRNAs}

Mature miRNA is generated via two-step cleavage of primary miRNA in both nuclear and cytoplasmic. The most of miRNA-coding genes are located in the introns of protein-coding genes, and the introns or exons of non-coding genes ${ }^{12}$. In canonical pathway, miRNAs are mainly transcribed by RNA polymerase II (RNA pol II)dependent from their own promoter or the promoter of the host genes in which they inside, and its controlled by RNA pol II-associated transcription factors and epigenetic regulators ${ }^{13,14}$. Resulting in synthesis of large miRNA precursors called primary miRNA (pri-miRNA), which contains local hair-spin structure, that varies from hundreds to thousands of base pairs in length ${ }^{13-15}$. The 577 methyl-guanosine capped and 3' polyadenylated miRNA are cleavage at the stem of hair-spin structures, releases a 60-70 nucleotide hair-spin structure termed the precursor miRNA (pre-miRNA). This process takes place in nucleus and catalyzed by the microprocessor, con-

${ }^{*}$ Author for correspondence 
tains the nuclear RNase III-type protein Drosha and its cofactor DiGeorge syndrome critical region 8 (DGCR8) protein in human (or Pasha protein in Drosophila melanogaster and Caenorhabditis elegans) ${ }^{16}$. The pre-miRNA, then, is exported into the cytoplasm for further processing through the mediation of Exportin-5 (EXP 5), also originally known as a minor export factor for tRNAs, and Ras-Related Nuclear Protein Guanosine Triphosphate (RAN-GTP) ${ }^{17}$. Following export from the nucleus, the terminal loop of pre-miRNA is removed by RNA III Dicer and its cofactor Transactivation-Responsive RNA-Binding Protein (TRBP), releasing 20-22 nucleotide miRNA-duplex, contains two 5' phosphorylated sequence strands with 3' overhangs, named as mature miRNA guide strand and complementary passenger strand ${ }^{15,18}$. Subsequently, the miRNA-duplex loaded into an Argonaute protein (Ago protein) so as to generate the effector complex, termed the RNA-Induced Silencing Complex (RISC). The mature miRNA, also known as miRNA, preferentially derived from the guiding strand, remains in Ago, whereas the complementary passenger strand is degraded. Mature miRNA bound to the miRNAInduced Silencing Complex (miRISC), that participates in the regulation of gene expression through binding to the target mRNAs leading to the degradation of mRNA (in case of perfect pairing between the miRNAs-mRNA target pairing) or the blocking of mRNA translation (in case of imperfect pairing) $)^{10,19}$.

\section{1 miRNA-141}

miR-141, clustered with miR-200c, located at $12 \mathrm{p} 13.31$ (nt: 6964097-6964191, [+]), is belonged to the miR-200 family. The miR-200 family concludes five subfamilies, miR-200a, miR-200b, miR-200c, miR-141, and miR-429, which classified based on the sequence homology in their seed regions (Figure 1). The first subfamily group concludes miR-141 and miR-200a with the homologous sequence "AACACUG", the second one composed by miR-200b, miR-200c, and 429 with the homologous sequence "AAUACUG".

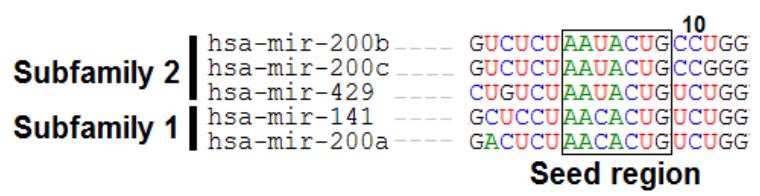

Figure 1. Two subfamilies of miR-200 family. Sequences of the five members of miR-200: miR-200a, miR-200b, miR200c, miR-141, and miR-429family were collected from miRNA database (http://www.mirbase.org) by following accession numbers: MI0000737, MI0000342, MI0000650, MI0000457, and MI0001641. The alignment was done by BioEdit Sequence Alignment Editor software.

Corresponding to current release of miRNA database (http://www.mirbase.org), the mature miR-141 composes two mature sequences, termed hsa-miR-141-5p (has-miR-141*) and hsa-miR-141-3p (has-miR-141)

(a)
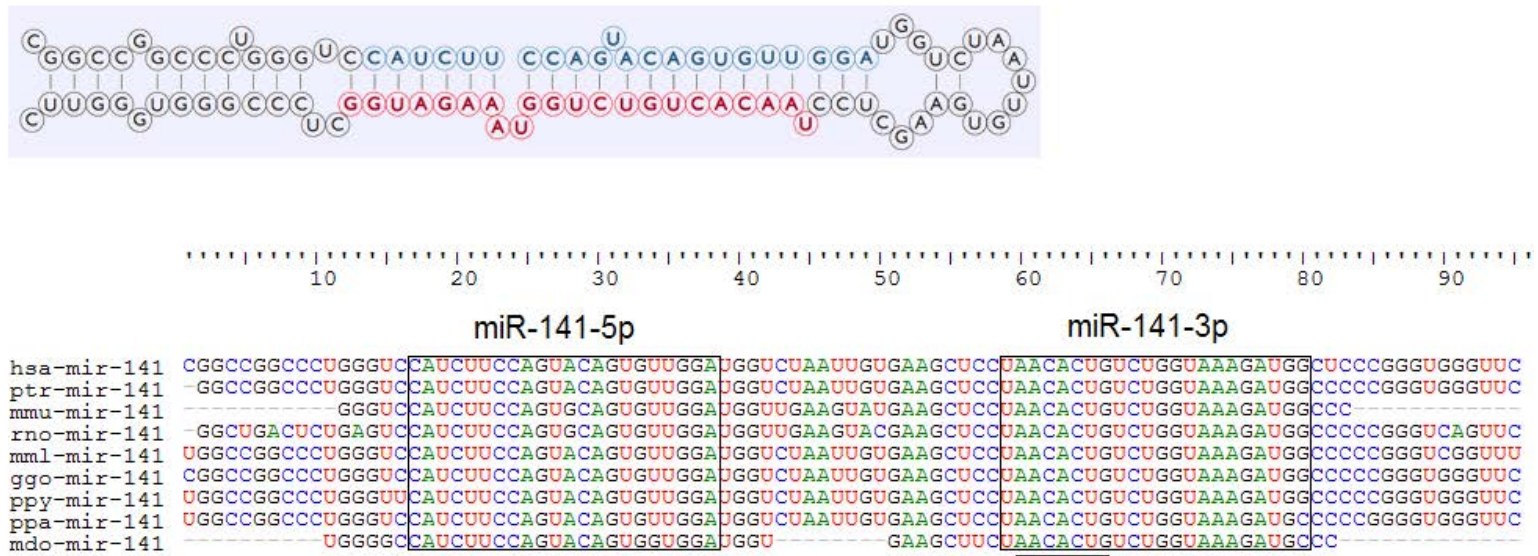

Seed region

Figure 2. (a) The schematic representation of the hairpin structure of the pre-miR-141. The mature of miR-141-3p (the guiding strand) is indicated in red. The miR-141-5p (the complementary passenger strand, previously termed miR-141*) is indicated in blue; (b) The highly conserved nucleotides of miR-141 is observed in many species: ptr: Pan troglodytes; hsa: Homo sapiens; mmu: Mus musculus; rno: Rattus norvegicus; mml: Macaca mulatta; ggo: Gorilla gorilla; ppy: Pongo pygmaeus; ppa: Pan paniscus; mdo: Monodelphis domestica. 
(Figure 2(a)), and showed the highly conversed in many species (Figure 2(b)).

\section{2 miR-141 Functions as Both Tumor Suppressor Gene and Oncogene to Regulate Human Cancers}

\subsubsection{Functions of miR-141 Expression in Various Human Cancers}

Up to date, a great deal of researches demonstrated miRNAs expression is a defining trait of tumorigenesis: Amplification or overexpression of miRNAs could act as the tumor suppressor genes, that downregulates different proteins with oncogenic activities; they act as the oncogenes, that suppresses the activities of tumor suppressor genes leads to the over proliferation, angiogenesis and invasion ${ }^{19,20}$. An interesting case is presented bymiR141, which was associated to human various cancers, including nasopharyngeal carcinoma ${ }^{5,20}$, hepatocellular carcinoma ${ }^{21-23}$, colon cancer ${ }^{24,25}$, prostate cancer ${ }^{26-28}$, bladder cancer ${ }^{28,29}$, ovarian cancer ${ }^{30-32}$, breast cancer ${ }^{34-36}$ etc. Considering to the role of miR-141, it is suggested to possess the dual roles in human tumorigenicity: functions as both oncogenic or tumor suppressive roles in human malignancies (Table 1).

\subsection{Tumor Suppressor miR-141}

A great deal of researches has been carried out to find out the role of miR-141 in human malignancies. The deregu- lated miR-141was screened out in various human cancers and suggested to be tumorigenesis activities. For instance, previous studies reported that miR-141 was downregulated in Hepatocellular Carcinoma (HCC), Renal Cell Carcinoma (RCC), Gastric Carcinoma (GC). In this case, Wu et al. (2014) ${ }^{22}$ reported that the expression of miR-141 was significant decreased in 4 HCC cell lines, includes HepG2, SMMC-7721, Huh7, and QGY-7703 ${ }^{22}$. In their research, they found that the expression of miR-141 suppressed both the growth and the motility of HCC cells by targeting the Zinc finger E-box Binding homeobox 2 (ZEB2) gene through the binding between the binding sites of miR-141 and the ZEB2 3'-UTR (Figure 3). ZBB2 gene is a member of the $\delta \mathrm{EF}-1$ family (or ZEB family) of two-handed zinc finger nuclear factors, which encoded protein, ZEB2, a transcriptional factor that that involves in many signaling pathways ${ }^{37}$. The expression of ZEB2 has so far been reported in many human cancers by induced the Epithelial to Mesenchymal Transition (EMT) through the inhibition of the expression E-cadherin as well as other genes coding for crucial proteins of tight junctions, desmosomes, and gap junction, leads to the promotion of tumor progression and metastasis 22,37 . Additionally, consistent with the results of Wu et al., ${ }^{22}$ study, they also found that the expression of miR-141 suppresses the cell proliferation, migration and invasion of HCC cell by targeting the Tiam 1 which was shown to act as a metastasis-related gene in a variety of cancers. miR-141 also could inhibit the proliferation and invasion and promote the apoptosis of HepG 2 cell by silencing HNF-3 $\beta^{23}$. Therefore, miR-141

Table 1. Dysregulation of miR-141 in many various human cancers

\begin{tabular}{|c|c|c|c|c|}
\hline Types of cancer & Expression of miR-141/ role & Target genes & Involved pathway & Reference \\
\hline $\begin{array}{l}\text { Nasopharyngeal } \\
\text { carcinoma }\end{array}$ & Upregulation/ Oncogene & BDR3, PTEN, UBAP1 & $\begin{array}{l}\text { Rb/E2F, JNK2, } \\
\text { PTEN/AKT }\end{array}$ & 5,20 \\
\hline Colon cancer & Upregulation/ Oncogene & MAP2K4; SIP1 & $\begin{array}{l}\text { miR-141-MAP2K4; } \\
\text { ZEB1/SIP1 }\end{array}$ & 25 \\
\hline Prostate cancer & Upregulation/ Oncogene & KLF9, shp & miR-141-3p/KLF9 & 28,34 \\
\hline Bladder cancer & Upregulation/ Oncogene & & & 29,30 \\
\hline Ovarian cancer & Upregulation/ Oncogene & KEAP1, p38a & NF-kB, Nrf2 & $31,32,33$ \\
\hline $\begin{array}{l}\text { Hepatocellular } \\
\text { carcinoma }\end{array}$ & Downregulation/ tumor suppressor & ZEB2, Tiam1, HNF-3 $\beta$, & HNF-3 $\beta$ & $21,22,23$ \\
\hline Renal cell carcinoma & Downregulation/ tumor suppressor & EphA2 & $\begin{array}{l}\text { EphA2/p-FAK/p- } \\
\text { AKT/MMPs }\end{array}$ & 38,39 \\
\hline \multirow[t]{2}{*}{ Breast cancer } & Downregulation/ tumor suppressor & ANP32E, PR, Stat5a & & 34,36 \\
\hline & Upregulation/Oncogene & & FAK and PI3K/AKT & 35 \\
\hline
\end{tabular}


was highlighted the importance of role as the tumor suppressor in HCC via the suppressing of many target genes, such as ZEB2, Tiam1, HNF-3 $\beta$.

The downregulation of miRNA was also found in Renal Cell Carcinoma (RCC) ${ }^{38,39}$. In details, on the research of Chen et al. ${ }^{39}$, a total of 74 miRNAs were dysregulated in renal cell carcinoma compared with normal tissue, they found that, in the case of miR-141, it was remarkably downregulated in RCC tissue (counting for 92.6\%) and concluded would serve as a promising biomarker for discriminating RCC from the normal tissue with the area under the receiver operating characteristics curve of 0.93 . Moreover, they also found that miR-141 plays a crucial suppressor role in RCC development and metastasis by targeting erythropoietin-producing hepatocellular A2 (EphA2) through modulating the EphA2/p-FAK/p-AKT/ MMPs signaling cascade. These results indicated miR-141 was downregulated, functioning as a tumor suppressor by inhibit the cell proliferation, migration as well as invasion of cancer cells.

\subsection{Oncogenic miR-141}

Among previous studies, miR-141 was reported to play an oncogenic role in human malignancies. For instance, miR-141 was found to be significantly upregulated in Nasopharyngeal Carcinoma (NPC) specimens in comparison with normal nasopharyngeal epithelium by qRT$\mathrm{PCR}^{20}$. They then found that miR-141 plays oncogenic activities to effect the cell proliferation, migration and invasion through positively regulated the $\mathrm{Rb} / \mathrm{E} 2 \mathrm{~F}$ and AKT pathway by targeting BRD3, PTEN, UBAP1. The $\mathrm{Rb} / \mathrm{E} 2 \mathrm{~F}$ pathway is essential for the normal cell cycle in which cell progression transfer phase G1 into phase $\mathrm{S}^{40}$. The AKT pathway plays an important role in the activation of cascade of different target proteins that involved in the cell growth, proliferation and migration. The phosphorylation of AKT is negative regulated by PTEN, which was identified as a tumor suppressor gene, plays a key role in plays an important role to result in the activation of cascade of different protein targets involved in cell growth, proliferation and invasion, and promote tumorigenesis ${ }^{20}$. According to the research of Zhang et al., ${ }^{20}$ the expression of miR-141 may increase the phosphorylation of AKT via the inhibition of PTEN expression. BDR3, plays a role in the regulation of transcription, probably by chromatin remodeling and interaction with transcription factors, has been also reported as negative regulator of $\mathrm{Rb} /$ E2F pathway. Moreover, the tumor-related gene c-MYC, SPLUNC1 may also constitute network to contribute NPC development. Therefore, miR-141 plays a role as an oncogene to affect NPC cell cycle, migration and invasion by positive regulation of $\mathrm{Rb} / \mathrm{E} 2 \mathrm{~F}$ and $\mathrm{AKT}$ pathway (Figure 4). The upregulation of miRNA was also observed in colorectal carcinoma. The expression levels of miR141 were significantly upregulated in clinical samples of colonic adenocarcinoma compared to non-cancerous tissue samples ${ }^{25}$. Moreover, they also found that the overexpression of miR-141 resulted in cell proliferation of CAC by inhibiting MAP2K4 activity. The upregulation of miR141 has been described in many types of human tumors, such as colon cancer, ovarian cancer, bladder cancer, etc.

The dysregulation of miR-141 expression occurs in multiple types of human cancers, that miR-141 plays a dual role in human tumorigenicity, functioning either as a tumor suppressor gene or oncogene.

\subsection{Circulating miR-141 is served as Prognosis and Diagnosis Biomarkers for} Cancers

Finding the capable biomarker, which is required to be stable, easily accessed in samples, for cancer prognosis and diagnosis has become a necessary work to increase the rate of patients' survival. Since the discovery of the first miRNAs in 2007, up to date, the dysregulation of miRNAs has been shown in many human tumorigenesis, thus, the analysis of miRNAs features may enable a better prediction of the cancer development ${ }^{41}$. In recent years, the expression of circulating miRNA has been detected in a variety of body fluids such as plasma, serum, saliva,

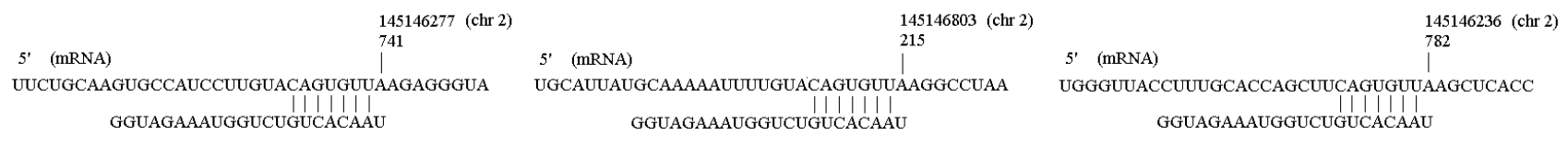

Figure 3. Schematic diagram of three potential binding sites of miR-141 in the ZEB2 3'-UTR (ENSG00000169554). The potential targets of miR-141 (hsa-miR-141-3p) were analyzed by miRmap (http://mirmap.ezlab.org). 


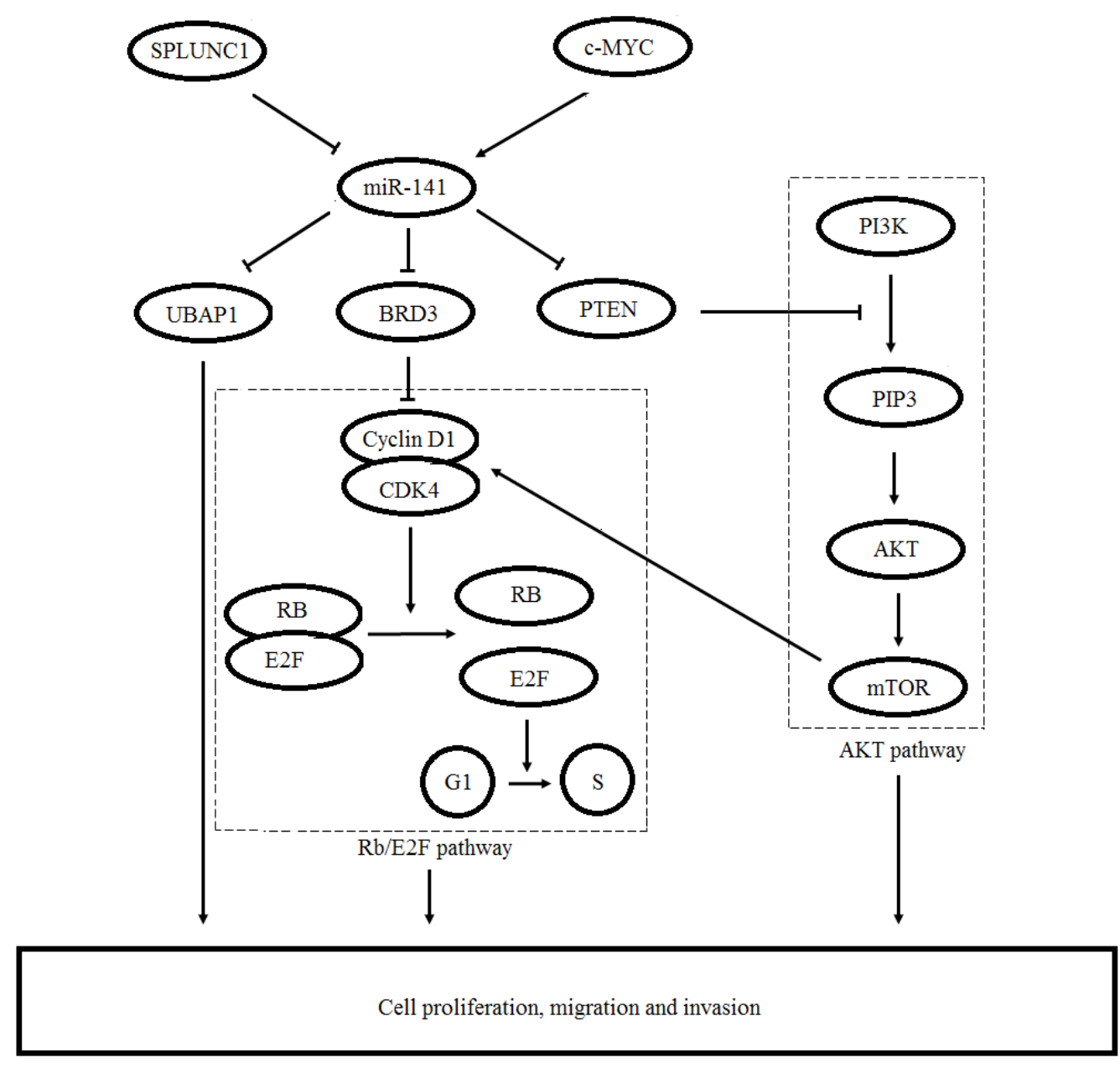

Figure 4. Signaling pathway of miR-141 related to NPC.

etc. and has been used as the potential biomarker in many human diseases, including cancers ${ }^{42,43}$. The use of miRNA seems to be more advantageous due to the stability of miRNAs in body fluids as well as the origin of miRNA ${ }^{42,43}$. Circulating miRNA, directly released by cancer cells, has been reported that they could pass the between cells or tissues and organs through blood circulation, bound to ribonucleoprotein complexes or in extracellular vesicles, such as micro-vesicles, exosomes or apoptotic bodies, which provides the protection from nuclease present abundantly in the body fluids, thus, making them highly stable and resistant to bedegraded ${ }^{44,45}$. These characteristics make miRNAs to be the potential and valuable as novel biomarkers for cancer diagnosis and prognosis.

In the case of miR-141, for instance, Brase et al., ${ }^{27}$ studies about the potential clinical relevance of miRNAs in serum (in total of screening 667 miRNAs, includ- ing miR-141) from prostate cancer patients. In their research, miR-375, miR-141, and miR-200b were shown the significant correlation with clinical parameters, such as Prostate-Specific Antigen (PSA). Significantly, both miR-375 and miR-141 were indicated a better performance for discrimination of patients with high-risk tumors (Gleason score $7 \geq 8$ ) from those with Gleason score 7 prostate cancers ${ }^{27}$. These results were also to be agreed with the conclusion of Mitchell et al. ${ }^{46}$ that circulating miR-141 (serum levels of miR-141) could distinguish between patients with metastatic prostate cancer and healthy controls ${ }^{46}$. The miR-141 was also acted as potential biomarker of therapeutic response in prostate cancer patients ${ }^{47}$. In their study, it was designed to compare the clinical valuable markers, such as Prostate-Specific Antigen (PSA), Circulating Tumor Cells (CTC) with miR-141 and compared miR-141 val- 
ues in response to prostate cancer treatment. As the results, a significant correlation between clinical course and miR-141 levels was observed; additionally, logistic regression modeling of the probability of clinical progression demonstrates that miR-141 levels predicted clinical outcomes with an odds ratio of at least 8.3. They concluded that a strong correlation between clinical course and miR-141 levels; thus, it potentially could be a useful tool for evaluating prognosis or treatment efficacy, and perhaps the full utility of miR-141 could be in a combinatorial, multivariate panel with other validated markers. Circulating MiR-141 has also reported to be a potential biomarker for the molecular diagnosis and prognosis in many human cancers, such as ovarian cancer $^{45,48}$, Colorectal cancer ${ }^{49}$ etc. Thus, the circulating miR-141 may represent a novel biomarker for diagnosis and prognosis in various human cancers.

\section{Conclusion}

In this review, we highlighted the biogenesis of miRNA, as well as the roles of miR-141 in many human cancers. Additionally, the dysregulation of miR-141 represented easily detectable biomarkers to predict and prognosis human cancers. The further insight of the biological effects of miRNA as well as miR-141 provides our understanding of this processing of complex malignancy to provide more useful prognosis biomarkers and novel therapeutic targets for human cancer treatment in the future.

\section{Acknowledgement}

We wish to express our thanks to the research project sponsored by Ministry of Education and Training, Vietnam; Ho Chi Minh City Department of Science and Technology; Ho Chi Minh City Open University, Ho Chi Minh City, Vietnam.

\section{Author's Contribution}

Thuan LD 40\%; Phuong TK 30\%; Thuy LHA 30\%. All authors read and approved the final manuscript.

\section{Availability of Data and Material}

Data sharing not applicable to this article as no datasets were generated or analyzed during the current study

\section{Funding}

The research project sponsored by Ministry of Education and Training, Vietnam; Ho Chi Minh City Department of Science and Technology; Ho Chi Minh City Open University, Ho Chi Minh City, Vietnam.

\section{References}

1. Croce CM, Calin GA. miRNAs, cancer, and stem cell division. Cell. 2005; 122(1):6-7. Crossref PMid:16009126

2. Lee RC, Feinbaum RL, Ambros V. The C. elegans heterochronic gene lin-4 encodes small RNAs with antisense complementarity to lin-14. Cell. 1993; 75(5):843-54. Crossref

3. Ha M, Kim VN. Regulation of microRNA biogenesis. Nat Rev Mol Cell Biol. 2014; 15(8):509-24. Crossref PMid:25027649

4. Filipowicz W, Bhattacharyya SN, Sonenberg N. Mechanisms of post-transcriptional regulation by microRNAs: are the answers in sight? Nat Rev Genet. 2008; 9(2):102-14. Crossref PMid:18197166

5. Liu $Y$, Zhao R, Wang H, Luo Y, Wang X, Niu W, et al. miR-141 is involved in BRD7-mediated cell proliferation and tumor formation through suppression of the PTEN/AKT pathway in nasopharyngeal carcinoma. Cell Death Dis. 2016; 24(7):e2156. Crossref PMid:27010857 PMCid:PMC4823963

6. Bushati N, Cohen SM. microRNA functions. Annu Rev Cell Dev Biol. 2007; 23:175-205. Crossref PMid:17506695

7. Calin GA, Croce CM. MicroRNA signatures in human cancers. Nat Rev Cancer. 2006; 6(11):857-66. Crossref PMid:17060945

8. Iorio MV, Croce CM. MicroRNAs in cancer: small molecules with a huge impact. J Clin Oncol. 2009; 27(34):5848-56. Crossref PMid:19884536 PMCid:PMC2793003

9. Spence T, Bruce J, Yip KW, Liu FF. MicroRNAs in nasopharyngeal carcinoma. Chin Clin Oncol. 2016; 5(2):17. Crossref PMid:27121877

10. Bartel DP. MicroRNAs: genomics, biogenesis, mechanism, and function. Cell. 2004; 116(2):281-97. Crossref

11. Macfarlane LA, Murphy PR. MicroRNA: Biogenesis, function and role in cancer. Curr Genomics. 2010; 11(7):537-61. Crossref PMid:21532838 PMCid:PMC3048316

12. Lin SL, Kim H, Ying SY. Intron-mediated RNA interference and microRNA (miRNA). Front Biosci. 2008; 13:2216-30. Crossref PMid:17981704

13. Cai X, Hagedorn CH, Cullen BR. Human microRNAs are processed from capped, polyadenylated transcripts that can also function as mRNAs. RNA. 2004; 10(12):1957-66. Crossref PMid:15525708 PMCid:PMC1370684 
14. Lee Y, Kim M, Han J, Yeom KH, Lee S, Baek SH, Kim VN. MicroRNA genes are transcribed by RNA polymerase II. EMBO J. 2004; 23(20):4051-60. Crossref PMid:15372072 PMCid:PMC524334

15. Kim VN, Han J, Siomi MC. Biogenesis of small RNAs in animals. Nat Rev Mol Cell Biol. 2009; 10(2):126-39. Crossref PMid:19165215

16. Lee Y, Ahn C, Han J, Choi H, Kim J, Yim J, et al. The nuclear RNase III Drosha initiates microRNA processing. Nature. 2003; 425(6956):415-9. Crossref PMid:14508493

17. Yi R, Qin Y, Macara IG, Cullen BR. Exportin-5 mediates the nuclear export of pre-microRNAs and short hairpin RNAs. Genes and Development. 2003; 17(24):3011-6. Crossref PMid:14681208 PMCid:PMC305252

18. Inui M, Martello G, Piccolo S. MicroRNA control of signal transduction. Nat Rev Mol Cell Biol. 2010; 11(4):252-63. Crossref PMid:20216554

19. Shenouda SK, Alahari SK. MicroRNA function in cancer: oncogene or a tumor suppressor? Cancer Metastasis Rev. 2009; 28(3-4):369-78. Crossref PMid:20012925

20. Zhang L, Deng T, Li X, Liu H, Zhou H, Ma J, et al. microRNA-141 is involved in a nasopharyngeal carcinomarelated genes network. Carcinogenesis. 2010; 31(4):559-66. Crossref PMid:20053927

21. Liu Y, Ding Y, Huang J, Wang S, Ni W, Guan J, et al. MiR141 suppresses the migration and invasion of HCC cells by targeting Tiam1. PLoS One. 2014; 9(2):e88393. Crossref PMid:24551096 PMCid:PMC3923786

22. Wu SM, Ai HW, Zhang DY, Han XQ, Pan Q, Luo FL, et al. MiR-141 targets ZEB2 to suppress HCC progression. Tumour Biol. 2014; 35(10):9993-7. Crossref_PMid:25008569

23. Lin L, Liang $\mathrm{H}$, Wang $\mathrm{Y}$, Yin $\mathrm{X}, \mathrm{Hu} \mathrm{Y}$, Huang J, et al. microRNA-141 inhibits cell proliferation and invasion and promotes apoptosis by targeting hepatocyte nuclear factor-3 $\beta$ in hepatocellular carcinoma cells. BMC Cancer. 2014; 14:879. Crossref PMid:25425543 PMCid:PMC4289273

24. Hu M, Xia M, Chen X, Lin Z, Xu Y, Ma Y, et al. MicroRNA-141 regulates Smad interacting protein 1 (SIP1) and inhibits migration and invasion of colorectal cancer cells. Dig Dis Sci. 2010; 55(8):2365-72. Crossref PMid:19830559

25. Ding L, Yu LL, Han N, Zhang BT. miR-141 promotes colon cancer cell proliferation by inhibiting MAP2K4. Oncol Lett. 2017; 13(3):1665-71. Crossref PMid:28454307 PMCid:PMC5403415

26. Li JZ, Li J, Wang HQ, Li X, Wen B, Wang YJ. MiR-141-3p promotes prostate cancer cell proliferation through inhibiting kruppel-like factor-9 expression. Biochem Biophys Res Commun. 2017; 482(4):1381-6. Crossref PMid:27956179

27. Brase JC, Johannes M, Schlomm T, Fälth M, Haese A, Steuber $\mathrm{T}$, et al. Circulating miRNAs are correlated with tumor progression in prostate cancer. Int J Cancer. 2011; 128(3):608-16. Crossref PMid:20473869

28. Xiao J, Gong AY, Eischeid AN, Chen D, Deng C, Young $\mathrm{CY}$, et al. miR-141 modulates androgen receptor transcriptional activity in human prostate cancer cells through targeting the small heterodimer partner protein. Prostate. 2012; 72(14):1514-22. Crossref PMid:22314666

29. Wang XL, Xie HY, Zhu CD, Zhu XF, Cao GX, Chen XH, et al. Increased miR-141 expression is associated with diagnosis and favorable prognosis of patients with bladder cancer. Tumour Biol. 2015; 36(2):877-83. Crossref PMid:25304156

30. Mahdavinezhad A, Mousavi-Bahar SH, Poorolajal J, Yadegarazari R, Jafari M, Shabab N, et al. Evaluation of miR141, miR-200c, miR-30b expression and clinicopathological featuresofbladdercancer.IntJMolCell Med.2015;4(1):32-9. PMid:25815280 PMCid:PMC4359703

31. van Jaarsveld MT, Helleman J, Boersma AW, van Kuijk PF, van Ijcken WF, Despierre E, et al. miR-141 regulates KEAP1 and modulates cisplatin sensitivity in ovarian cancer cells. Oncogene. 2013; 32(36):4284-93. Crossref PMid:23045278

32. Chen JL, Chen F, Zhang TT, Liu NF. Suppression of SIK1 by miR-141 in human ovarian cancer cell lines and tissues. Int J Mol Med. 2016; 37(6):1601-10. Crossref PMid:27081781

33. Mateescu B, Batista L, Cardon M, Gruosso T, de Feraudy Y, Mariani O, et al. miR-141 and miR-200a act on ovarian tumorigenesis by controlling oxidative stress response. Nat Med. 2011; 17(12):1627-35. Crossref PMid:22101765

34. Li $P, X u ~ T$, Zhou $X$, Liao L, Pang G, Luo W, et al. Downregulation of miRNA-141 in breast cancer cells is associated with cell migration and invasion: Involvement of ANP32E targeting. Cancer Med. 2017; 6(3):662-72. Crossref PMid:28220627 PMCid:PMC5345683

35. Choi SK, Kim HS, Jin T, Hwang EH, Jung M, Moon WK. Overexpression of the miR-141/200c cluster promotes the migratory and invasive ability of triple-negative breast cancer cells through the activation of the FAK and PI3K/AKT signaling pathways by secreting VEGF-A. BMC Cancer. 2016; 16:570. Crossref PMid:27484639 PMCid:PMC4969651

36. Finlay-Schultz J, Cittelly DM, Hendricks P, Patel P, Kabos P, Jacobsen BM, et al. Progesterone downregulation of miR141 contributes to expansion of stem-like breast cancer cells through maintenance of progesterone receptor and Stat5a. Oncogene. 2015; 34(28):3676-87. Crossref PMid:25241899 PMCid:PMC4369481

37. Vandewalle C, Comijn J, De Craene B, Vermassen P, Bruyneel E, Andersen H, et al. SIP1/ZEB2 induces EMT by repressing genes of different epithelial cell-cell junctions. Nucleic Acids Research. 2005; 33(20):6566-78. Crossref PMid:16314317 PMCid:PMC1298926 
38. Tang $\mathrm{K}, \mathrm{Xu} \mathrm{H}$. Prognostic value of meta-signature miRNAs in renal cell carcinoma: An integrated miRNA expression profiling analysis. Scientific Reports. 2015; 5:10272. Crossref PMid:25974855 PMCid:PMC4431463

39. Chen X, Wang X, Ruan A, Han W, Zhao Y, Lu X, et al. miR-141 is a key regulator of renal cell carcinoma proliferation and metastasis by controlling EphA2 expression. Clin Cancer Res. 2014; 20(10):2617-30. Crossref PMid:24647573

40. Walworth NC. Cell-cycle checkpoint kinases: Checking in on the cell cycle. Curr Opin Cell Biol. 2000; 12(6):697-704. Crossref

41. Tricoli JV, Jacobson JW. MicroRNA: Potential for cancer detection, diagnosis, and prognosis. Cancer Res. 2007; 67(10):4553-5. Crossref PMid:17510380

42. Macha MA, Seshacharyulu P, Krishn SR, Pai P, Rachagani $\mathrm{S}$, Jain $\mathrm{M}$, et al. MicroRNAs (miRNAs) as biomarker(s) for prognosis and diagnosis of gastrointestinal (GI) cancers. Curr Pharm Des.2014; 20(33):5287-97. Crossref PMid:24479799 PMCid:PMC4113605

43. Fendler A, Stephan C, Yousef GM, Kristiansen G, Jung $\mathrm{K}$. The translational potential of microRNAs as biofluid markers of urological tumours. Nat Rev Urol. 2016; 13(12):734-52. Crossref PMid:27804986

44. Valadi H, Ekström K, Bossios A, Sjöstrand M, Lee JJ, Lötvall JO. Exosome-mediated transfer of mRNAs and microRNAs is a novel mechanism of genetic exchange between cells. Nat Cell Biol. 2007; 9(6):654-9. Crossref PMid:17486113

45. Zheng H, Liu JY, Song FJ, Chen KX. Advances in circulating microRNAs as diagnostic and prognostic markers for ovarian cancer. Cancer Biology and Medicine. 2013; 10(3):123-30. PMid:24379986 PMCid:PMC3860338

46. Mitchell PS, Parkin RK, Kroh EM, Fritz BR, Wyman SK, Pogosova-Agadjanyan EL, et al. Circulating microRNAs as stable blood-based markers for cancer detection. Proc Natl Acad Sci U S A. 2008; 105(30):10513-8. Crossref PMid:18663219 PMCid:PMC2492472

47. Gonzales JC, Fink LM, Goodman OB Jr, Symanowski JT, Vogelzang NJ, Ward DC. Comparison of circulating
MicroRNA 141 to circulating tumor cells, lactate dehydrogenase, and prostate-specific antigen for determining treatment response in patients with metastatic prostate cancer. Clin Genitourin Cancer. 2011; 9(1):39-45. Crossref PMid:21723797

48. Antolín S, Calvo L, Blanco-Calvo M, Santiago MP, LorenzoPati-o MJ, Haz-Conde M, et al. Circulating miR-200c and miR-141 and outcomes in patients with breast cancer. BMC Cancer. 2015; 15:297. Crossref PMid:25885099 PMCid:PMC4405843

49. Cheng H, Zhang L, Cogdell DE, Zheng H, Schetter AJ, Nykter M, et al. Circulating plasma MiR-141 is a novel biomarker for metastatic colon cancer and predicts poor prognosis. PLoS One. 2011; 6(3):e17745. Crossref PMid:21445232 PMCid:PMC3060165

\section{List of Abbreviations}

3'-UTR: 3'- Untranslated Region;

Ago protein: Argonaute Protein;

DGCR8: DiGeorge Syndrome Critical Region 8;

EMT: Mesenchymal Transition;

EphA2: Erythropoietin-Producing Hepatocellular A2;

EXP 5: Exportin-5;

GC: Gastric Carcinoma;

HCC: Hepatocellular Carcinoma;

miR-141: microRNA-141;

miRISC: miRNA-induced Silencing Complex;

NPC: Nasopharyngeal Carcinoma;

pre-miRNA: Precursor miRNA;

pri-miRNA: Primary miRNA;

RAN-GTP: Ras-related Nuclear Protein Guanosine Triphosphate;

RCC: Renal Cell Carcinoma;

RISC: RNA-Induced Silencing Complex;

TRBP: Transactivation-Responsive RNA-Binding Protein; ZEB2: Zinc Finger E-box Binding Homeobox 2. 